\title{
PENGGUNAAN MODEL BERBAHAN KAIN FLANNEL UNTUK MENINGKATKAN KOMPETENSI DAN KEPERCAYAAN DIRI MAHASISWA KEBIDANAN DALAM TEKNIK PENJAHITAN LUKA PERINEUM
}

* Rery Kurniawati D.I

\begin{abstract}
Abstrak
Teknik penjahitan merupakan kompetensi yang harus dimiliki seorang bidan.Keterbatasan model yang digunakan berakibat terhadap kurangnya kompetensi mahasiswa dalam melakukan praktik penjahitan perineum.Perlu dilakukan penelitian terkait material dan model yang ideal untuk pembelajaran teknik penjahitan luka perineum. Oleh karena itu penelitian ini bertujuan mengetahui efektifitas penggunaan model berbahan kain flannel untuk praktik penjahitan luka perineum pada mahasiswa Jurusan Kebidanan Rangkasbitung, Banten.

Penelitian dirancang menggunakan desain eksperimental dengan metode postest design only.Besar sampel ditentukan berdasarkan jumlah minimal sampel eksperimen sejumlah 11 orang kelompok perlakuan dan 14 orang kelompok kontrol.Data dianalisis menggunakan uji Mann Whitney.

Hasil penelitian menunjukkan rerata kompetensi penjahitan perineum pada kelompok model lebih tinggi (83) dari pada kelompok non model (74). Dari hasil uji statistic didapatkan $\mathrm{p}=0.002$ artinya ada perbedaan bermakna antara kompetensi penjahitan perineum pada kelompok model dengan kelompok non model. Pada tingkat kepercayaan diri responden dalam melakukan penjahitan perineum baik pada kelompok model maupun kelompok non model mempunyai rerata yang sama (4) dengan nilai $\mathrm{p}=0.651$. Selanjutnya pada variabel lama waktu penjahitan diketahui rerata kelompok model sedikit lebih cepat (20 menit) daripada rerata pada kelompok non model (22 menit) dengan nilai $\mathrm{p}=0.978$. Tidak ada perbedaan bermakna pada kedua variable tersebut.

Hasil penelitian sesuai dengan Hammound (2008) yang menyatakan bahwa media pembelajaran yang memiliki tingkat kenyataan yang tinggi (high fidelity) membuat mahasiswa mempunyai ketertarikan yang lebih dalam proses pembelajaran.

Disarankan perlu penelitian lebih lanjut tentang media penjahitan yang efisien sehingga lama waktu dan kepercayaan diri dapat lebih baik.
\end{abstract}

Kata Kunci: Model, Kompetensi Penjahitan, Perineum.

*Dosen Jurusan Kebidanan Poltekkes Banten 


\title{
USE OF MODEL BASED FLANNEL TO INCREASE COMPETENCE AND CONFIDENCE OF MIDWIFERY STUDENTS IN PERINEAL SUTURING TECHNIQUES \\ * Rery Kurniawati D.I
}

\begin{abstract}
Suturing techniques are competencies that must be owned by a midwife. Limitations of the model used consequential to the lack of competence of the students in practicing perineal suturing. Need to do research related to material and ideal model for learning techniques perineal suturing wounds. Therefore, this study aims to determine the effectiveness of the use of models made from flannel to practice suturing perineal wound on the students of Jurusan Kebidanan Rangkasbitung, Banten.

The study was designed to use an experimental design with methodposttest design only. The sample size is determined by the minimum number of the experimentalamount11 samples of treatment group and 14 control group. Data were analyzed using the Mann Whitney test.

The results showed a mean suturing perineal competence in model group was higher (83) than in the group of non-model (74). From the statistical test results obtained $p=0.002$ means that there are significant differences between the groups perineal suturing competency models with groups of non-models. At the level of confidence of respondents in performing perineal suturing both in the model group and non-group model has the same mean (4), with $p=0.651$. Furthermore, the length of time for suturingthe mean slightly faster model group (20 minutes) than in the group of non-model (22 minutes) with a value of $p=0978$. There is no significant difference in both these variables.

According to the research Hammound (2008) which states that media that have a high degree of reality (high fidelity) make students have more interest in the learning process.

Suggested need more research on media suturing efficient so much time and confidence can be better.

Keywords: Model, Competence Suturing, Perineum.

* Lecturer Jurusan Kebidanan Poltekkes Banten
\end{abstract}




\section{Pendahuluan}

Teknik penjahitan atau suturing merupakan salah satu kompetensi yang harus dimiliki seorang bidan pada tingkat pelayanan kesehatan dasar.Dalam kurikulum pendidikan diploma III Kebidanan, keterampilan ini merupakan salah satu kompetensi yang harus dicapai dalam mata kuliah Asuhan Kebidanan Pada Ibu Bersalin.

Saat ini, media pembelajaran untuk keterampilan penjahitan luka perineum menggunakan model berupa bantalan kain yang diisi kapuk dan daging paha ayam.Penggunaan bahan tersebut ini lebih mudah digunakan dan tersedia dengan jumlah yang tidak terbatas karena dapat disediakan sendiri oleh mahasiswa.Akan tetapi terdapat beberapa kekurangan karena model yang digunakan sangat jauh berbeda dengan bentuk dan struktur perineum yang sesungguhnya.Bahan tersebut tidak memberikan visualisasi yang jelas mengenai bentuk luka dan struktur perineum.Visualisasi yang benar dapat mempengaruhi kemampuan maupun kepercayaan diri mahasiswa dalam menerapkan kompetensi tersebut pada pasien nantinya. Model phantom luka perineum dari bahan sintetis yang tersedia juga tidak dapat dilakukan praktik penjahitan karena selain akan merusak materialnya harga yang harus dibayar pun sangat mahal.

Keterbatasan model yang digunakan untuk kompetensi tersebut berakibat terhadap kurangnya kompetensi mahasiswa dalam melakukan praktik penjahitan luka perineum

$$
\text { Teknik yang dipelajari }
$$
mahasiswa untuk penjahitan luka perineum adalah jelujur dan subkutikuler.Untuk melakukan kedua teknik penjahitan tersebut diperlukan suatu model yang sederhana, murah, dan dapat menggambarkan bentuk luka perineum secara jelas.Model yang dapat menggambarkan bentuk luka perineum secara sederhana sangatlah diperlukan karena mahasiswa dapat memperoleh visualisasi bentuk luka perineum yang dijahitnya.Untuk itu, perlu dilakukan penelitian terkait penggunaan berbagai material dan model yang ideal untuk pembelajaran teknik penjahitan luka perineum.

Penelitian ini dirancang menggunakan desain eksperimental dengan metode postest design only. Pelaksanaan penelitian terdiri dari tiga tahap, pertama dilakukan pengenalan tentang teknik penjahitan luka perineum 
pada mahasiswa, kedua kelompok perlakuan mempraktikan penjahitan luka perineum dengan rancangan/model penjahitan luka perineum berbahan kain flannel dan kelompok kontrol menggunakan bantalan kapuk/kapas. Pada tahap ini dilakukan penilaian keterampilan oleh dosen pembimbing dengan menggunakan daftar ceklist.Dan pada tahap ketiga responden mengisi kuesioner tingkat kepercayaan diri.Data hasil eksperimen tersebut selanjutnya diuji secara statistic dan dinilai tingkat kebermaknaan model yang digunakan.

\section{Metodologi Penelitian}

Penelitian ini dirancang menggunakan desain eksperimental dengan metode postest design only. Pelaksanaan penelitian terdiri dari tiga tahap, pertama dilakukan survey kepada mahasiswa terkait proses pembelajaran praktik penjahitan luka perineum, kedua secara paralel pada mahasiswa dikenalkandan dilatihkan keterampilan penjahitannya baik menggunakan rancangan/model penjahitan luka perineum berbahan kain flannel maupun model bantalan kapas. Dan tahap ketiga dilakukan evaluasi keterampilan mahasiswa
Dari penelitian terdahulu oleh Zainuddin (2013) diketahui tingkat kemampuan penjahitan jaringan dengan menggunakan hewan post mortem lebih tinggi dibandingkan dengan menggunakan bahan organik, walaupun hasil uji secara statistik tidak signifikan. Penelitian ini bertujuan untuk mengetahui efektifitas penggunaan model berbahan kain flannel untuk praktik penjahitan luka perineum oleh mahasiswa Jurusan Kebidanan Rangkasbitung.

baik pada kelompok perlakuan maupun kelompok control dengan melakukan penjahitan pada media uji berupa daging ayam. Penilaian keterampilan dilakukan oleh dosen dengan metode blinded examinationyaitu dosen yang memberikan penilaian tidak mengetahui responden yang dinilai termasuk dalam kelompok perlakuan atau kelompok kontrol.Selanjutnya dilakukan pengukuran kepercayaan diri mahasiswa menggunakan kuesioner. Hasil penilaian tersebut diuji secara statistik dan dinilai 
tingkat kebermaknaan model yang digunakan.

Populasi penelitian adalah mahasiswa Jurusan Kebidanan Rangkasbitung yang memenuhi kriteria sampel dan bersedia menjadi responden yang dinyatakan dalam surat persetujuan. Kriteria inklusi pemilihan sampel penelitian adalah mahasiswa yang bersedia menjadi responden dan belum kompeten dalam melakukan penjahitan luka perineum.Kriteria ekslusinya adalah mahasiswa yang sudah dinyatakan kompeten melakukan penjahitan luka

\section{Hasil}

Pada bagian ini akan disajikan hasil penelitian berupa nilai-nilai variabel penelitian antara kelompok
perineum.Dari 30 responden yang diambil 5 mahasiswa mengundurkan diri karena sakit dan ijin sehingga responden penelitian menjadi 25 orang terdiri dari 11 orang kelompok perlakuan dan 14 orang kelompok kontrol. Hal tersebut masih dalam sesuai dengan jumlah sampel penelitian eksperimen sebagaimana dikemukakan oleh Sugiyono, 2007 bahwa dalam penelitian eksperimen yang menggunakan kelompok eksperimen dan kelompok kontrol jumlah anggota sampel masingmasing 10-20 orang.

model (perlakuan) dan kelompok non model (control). Berikut ini adalah tabel data hasil penilaian efektifitas penggunaan model penjahitan perineum.

Tabel 1.

Data Hasil Penilaian Efektifitas Penjahitan Perineum Pada Kelompok Model

\begin{tabular}{lccc}
\hline No Responden & $\begin{array}{l}\text { Kompetensi } \\
\text { Penjahitan }\end{array}$ & Kepercayaan Diri & $\begin{array}{l}\text { Lama waktu } \\
\text { praktik }\end{array}$ \\
\hline R15 & 78 & 4 & 29 \\
\hline R16 & 84 & 3 & 25 \\
\hline R17 & 90 & 4 & 15 \\
\hline R18 & 77 & 4 & 23 \\
\hline R19 & 88 & 4 & 23 \\
\hline R20 & 86 & 4 & 12 \\
\hline R21 & 95 & 3 & 14 \\
\hline R22 & 70 & 4 & 14 \\
\hline R23 & 77 & 4 & 20 \\
\hline
\end{tabular}




\begin{tabular}{lccc}
\hline R24 & 84 & 3 & 26 \\
\hline R25 & 83 & 4 & 18 \\
\hline Jumlah & 912 & 41 & 219 \\
\hline Rerata & 83 & 4 & 20 \\
\hline
\end{tabular}

Dari tabel 1 diketahui rerata penjahitan luka perineum sebesar 83, variable efektifitas pada kelompok kepercayaan diri dengan nilai 4 dan model adalah pada kompetensi lama waktu sebesar 20 menit.

Tabel 2.

Data Hasil Penilaian Efektifitas Penjahitan Perineum

Pada Kelompok Non Model

\begin{tabular}{lccc}
\hline No Responden & Kompetensi Penjahital Kepercayaan Diri & $\begin{array}{l}\text { Lama waktu } \\
\text { praktik }\end{array}$ \\
\hline R1 & 73 & 5 & 23 \\
\hline R2 & 75 & 4 & 10 \\
\hline R3 & 78 & 3 & 19 \\
\hline R4 & 74 & 4 & 23 \\
\hline R5 & 80 & 4 & 13 \\
\hline R6 & 81 & 4 & 42 \\
\hline R7 & 76 & 3 & 20 \\
\hline R9 & 76 & 4 & 11 \\
\hline R10 & 74 & 3 & 18 \\
\hline R11 & 72 & 4 & 10 \\
\hline R13 & 71 & 3 & 24 \\
\hline R14 & 73 & 5 & 22 \\
\hline Jumlah & 74 & 4 & 29 \\
\hline Rerata & 59 & 4 & 46 \\
\hline & 1036 & 54 & 310 \\
\hline
\end{tabular}

Dari tabel 2 diketahui rerata variable efektifitas pada kelompok non model adalah pada kompetensi penjahitan luka perineum sebesar 74 , kepercayaan diri dengan nilai 4 dan lama waktu sebesar 22 menit.
Selanjutnya adalah tabel hasil uji beda antara efektifitas penjahitan luka perineum pada kelompok model dan non model. 
Tabel 3.

Perbandingan Antara Kelompok Model dan Kelompok Non Model

\begin{tabular}{cccccc}
\hline \multirow{2}{*}{ Variabel } & \multicolumn{2}{c}{ Kelompok Model } & \multicolumn{2}{c}{ Kelompok Non Model } & $\mathrm{P}$ \\
\cline { 2 - 6 } & $\mathrm{n}$ & $\mathrm{x}$ & $\mathrm{N}$ & $\mathrm{x}$ & \\
\hline Kompetensi & 912 & 83 & 1036 & 74 & 0.002 \\
\hline Kepercayaan Diri & 41 & 4 & 54 & 4 & 0.651 \\
\hline Lama Waktu & 219 & 20 & 310 & 22 & 0.978 \\
\hline $\mathrm{n}=$ nilai skor & & & & \\
$\mathrm{x}=$ rerata skor & & & & \\
$\mathrm{P}=$ nilai uji statistik & & & &
\end{tabular}

Dari tabel diketahui rerata kompetensi penjahitan perineum pada kelompok model lebih tinggi (83) dari pada kelompok non model (74). Dari hasil uji statistik terdapat distribusi data yang tidak normal sehingga dilakukan uji beda menggunakan uji mann whitney. Dari hasil uji tersebut didapatkan nilai yang bermakna antara kompetensi penjahitan perineum pada kelompok model dengan kelompok non model $\quad(p=0.002)$ Pada tingkat kepercayaan diri responden dalam

\section{Pembahasan}

Dari hasil penelitian diketahui kompetensi penjahitan perineum pada kelompok model lebih tinggi dari pada kelompok non model. Secara statistik kedua kelompok tersebut mempunyai nilai perbedaan yang bermakna. Analisa peneliti, penggunaan model jahit berbahan kain flannel mempunyai bentuk yang lebih mirip bentuk melakukan penjahitan perineum baik pada kelompok model maupun kelompok non model mempunyai rerata yang sama (4). Hasil uji statistic (uji mann whitney) didapatkan nilai yang tidak bermakna (0.651). Selanjutnya pada variabel lama waktu penjahitan diketahui rerata kelompok model sedikit lebih cepat (20 menit) daripada rerata pada kelompok non model (22 menit). Hasil uji statistic (uji mann whitney) didapatkan nilai yang tidak bermakna (0.978).

perineum, terdapat gambaran luka yang jelas dan perbedaan lapisan kulit yang jelas pula. Dengan visualisasi yang demikian responden lebih mudah memahami langkah/teknik penjahitan perineum yang diajarkan.Sedangkan pada kelompok non model hanya menggunakan bantalan kapas yang datar dan tidak ada visualisasi lapisanlapisan yang harus dijahit. 
Analisa diatas sesuai dengan teori yang menyatakan bahwa media pembelajaran yang memiliki tingkat kenyataan yang tinggi (high fidelity) membuat mahasiswa mempunyai ketertarikan yang lebih dalam proses pembelajaran (Hammound, 2008). Dalam hal ini model berbahan kain flannel mempunyai tingkat kenyataan yang lebih tinggi daripada bantalan kapas.

Hasil tersebut didukung pula pada lama waktu responden dalam melakukan penjahitan. Pada kelompok model lama yang dibutuhkan untuk menjahit perineum adalah 20 menit sedikit lebih cepat daripada kelompok non model yang mempunyai waktu 22 menit. Analisa peneliti, hal tersebut menunjukkan penggunaan model berbahan kain flannel membuat responden lebih cepat memahami kompetensi penjahitan sehingga waktu yang digunakan juga lebih sedikit. Hal tersebut karena secara sensoris pada model berbahan kain flannel menunjukkan bentuk visual yang mirip dengan bentuk perineum sehingga lebih mudah diterima oleh responden. Walaupun secara statistik tidak ada perbedaan yang bermakna pada kedua kelompok tersebut. Sebagaimana dikemukakan oleh Berlo cit Liliweri (2009) bahwa dalam tubuh manusia ada media sensoris. Mata untuk melihat, telinga untuk mendengar, dan manusia juga melakukan sentuhan-sentuhan. Terdapat hubungan yang mendukung antara penggunaan satu atau lebih saluran sensoris dalam proses penerimaan pesan.

$$
\text { Pada variabel tingkat }
$$
kepercayaan diri dalam melakukan penjahitan baik pada kelompok model maupun non model mempunya nilai yang sama. Secara statistik juga tidak ada perbedaan yang bermakna. Hal tersebut bisa jadi karena baik kelompok model maupun non model mempunyai kepercayaan yang tinggi dalam kompetensi penjahitan perineum. Berlatih menggunakan media apapun responden tetap percaya diri dapat melakukan penjahitan perineum. Tingginya nilai kepercayaan diri baik pada kelompok model maupun non model juga didukung oleh latar belakang karakteristik mahasiswa yang bersedia menjadi responden. Responden adalah mahasiswa-mahasiswa yang mempunyai konsep diri yang tinggi yaitu aktif dalam kegiatan pembelajaran, percaya diri, dan mempunyai keinginan belajar yang 
tinggi. Hal ini sesuai dengan pernyataan Liliweri (2009) bahwa bagi mereka yang mempunyai konsep diri yang tinggi jika diberikan informasi dapat

\section{Simpulan}

1. Kompetensi penjahitan perineum pada kelompok model berbahan flannel lebih baik daripada kelompok bantalan kapas dengan nilai perbedaan yang bermakna.

2. Lama waktu penjahitan pada kelompok model berbahan flannel lebih baik daripada kelompok bantalan kapas akan tetapi secara statistik tidak terdapat perbedaan yang bermakna.

3. Tingkat kepercayaan diri dalam melakukan penjahitan pada kelompok model berbahan flannel sama nilainya dengan kelompok bantalan kapas dan

\section{Daftar Pustaka}

Depkes RI, 2008, Asuhan Persalinan Normal, Jakarta.

FK UI, 2005, Ilmu Penyakit Kulit dan Kelamin Ed 4. Fakulitas Kedokteran Universitas Indonesia.

Hammoud MM, Nuthalapaty FS, Goepfert AR, etc. 2008, To the point: medical education review of the role of simulators in surgical training. Am J ObstetGynecol. 2008;199 (4):338-43. mengembangkan sendiri informasi yang didapatkan. Sehingga sikap percaya dirinya akan tinggi seiring banyaknya informasi yang didapatkan.

secara statistik tidak ada perbedaan yang bermakna.

Berdasarkan hasil penelitian ini disarankan perlu penelitian lebih lanjut tentang media penjahitan yang efisien sehingga lama waktu dan kepercayaan diri dapat lebih baik.Dan bagi mahasiswa perlu ada media penjahitan yang memberikan visualisai yang mirip dengan perineum dengan harga yang terjangkau dan didapat.

Liliweri A, 2009, Dasar-Dasar

Komunikasi Kesehatan, Pustaka

Pelajar, Yogyakarta.

Saifudin, A.B., 2002, Buku Panduan Praktis Pelayanan Kesehatan Maternal dan Neonatal, YBP-SP, Jakarta

Sjamsuhidajat R, De Jong Wim. Buku Ajar Ilmu Bedah. Edisi ke-2. Jakarta : Penerbit Buku Kedokteran EGC

Suharsaputra, Uhar. 2012, Metode Penelitian Kuantitatif, Kualitatif, dan Tindakan. Refika Aditama. 
Wiknjosastro, Hanifa, 2006, Ilmu Kebidanan, YBP-SP, Jakarta

Zainuddin Z, 2013, Pengaruh Penggunaan Media Pembelajaran Berupa Material Organik, Hewan Postmortem dan Sintetik Terhadap Kemampuan dan Kepercayaan Diri Mahasiswa Kedokteran Pada Teknik Penjahitan Jaringan Kulit, Program Studi Pendidikan Dokter Fakultas Kedokteran dan Ilmu Kesehatan Universitas Bengkulu. 